Clinical Image

\section{Severe hypertriglycerdemia in pregnancy}

\section{Krithika Muralidhara* and Shashank Dhareshwar}

Department of Nephrology, St Johns Medical College Hospital, Bangalore, India

31 year old female presented with abdominal pain and respiratory distress in the third trimester of her second pregnancy. Her blood workup revealed a lipemic sample (Figure 1) due to markedly elevated serum triglycerides of $8178 \mathrm{mg} / \mathrm{dl}$ (Glycerol Phosphate Oxidase method).

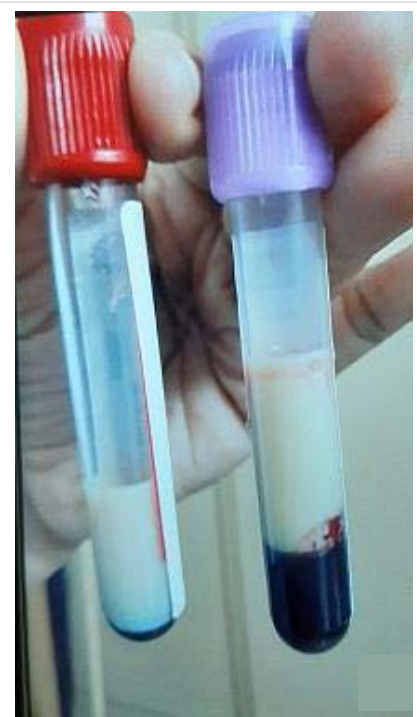

Figure 1: Lipemic blood sample during routine workup.

Total cholesterol and Low Density Lipoprotein were elevated at $1701 \mathrm{mg} / \mathrm{dl}$ and $788 \mathrm{mg} / \mathrm{dl}$ respectively. There was no family history of lipid disorders. Diagnosis was consistent with gestational hypertriglyceridemia with acute pancreatitis (Serum Amylase-50 U/L, Serum Lipase- 96 U/L), though genetic tests to rule out pre-existing primary hypertriglyceridemia was not feasible. In view of the life threatening condition, she was initiated on Insulin-Dextrose infusion and offered one session of Plasma Exchange. Figures 2,3 depict membrane plasma separation with the obtained effluent as lipemic plasma. Her serum triglycerides showed a declining trend and was discharged in good health (serum triglycerides at discharge- $651 \mathrm{mg} / \mathrm{dl}$ ).

\section{Acknowledgment}

We acknowledge the support by intensive care team.
More Information

*Address for Correspondence: Krithika Muralidhara, Assistant Professor, Department of Nephrology, St Johns Medical College Hospital, Bangalore, India, Email: krithidm@yahoo.co.in

Submitted: February 09, 2021

Approved: February 11, 2021

Published: February 12, 2021

How to cite this article: Muralidhara K, Dhareshwar S. Severe hypertriglycerdemia in pregnancy. Clin J Obstet Gynecol. 2021; 4: 019-019.

DOI: 10.29328/journal.cjog.1001080

Copyright: @ 2021 Muralidhara K, et al. This is an open access article distributed under the Creative Commons Attribution License, which permits unrestricted use, distribution, and reproduction in any medium, provided the original work is properly cited.

D) Check for updates

OPEN ACCESS

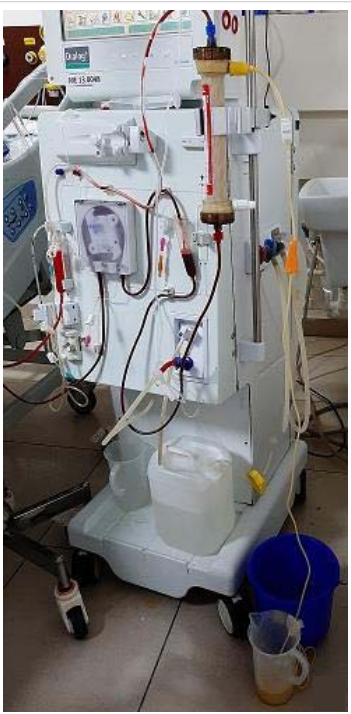

Figure 2: Membrane Plasma Exchange showing lipemic plasma in plasma filter.

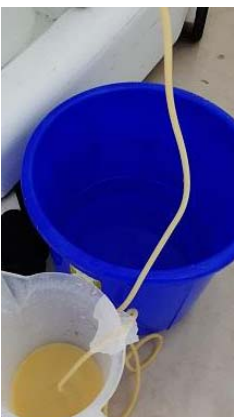

Figure 3: Lipemic plasma collected as effluent after plasma exchange. 